\title{
An Updated Checklist of Globally Threatened Species in Bhutan as Listed in IUCN Red List of Threatened Species
}

\author{
Manita $^{1}$, Tej Kumar Nepal ${ }^{2}$ \\ ${ }^{1}$ Student, Department of Arts \& Humanities, Sherubtse College, Royal University of Bhutan \\ ${ }^{2}$ Student, School of Ecology and Environment Studies, Nalanda University, Rajgir, Bihar, India \\ Corresponding author: tejkumarnepal97[at]gmail.com
}

\begin{abstract}
Bhutan lies to the East of Himalaya and it hosts around 11,248 species in all taxa. Bhutan's lush and green forest covers 71 percent of land which comes under the five National Parks, four Wildlife Sanctuaries, 1 Strict Nature Reserve, Community Forests and biological corridors connecting different protected areas. More than half (51.44 percent) is protected by law and activities are restricted under certain circumstances. It is home to Takin (Budorcastaxicolorwhitei), White-bellied Heron (Ardeainsignis), Black-necked Crane (Grusnigricollis), Red Panda (Ailurusfulgens), Great Hornbill (Bucerosbicornis) and Chinese Pangolin (Manispentadactyla) that are globally threatened.Bhutan contributed around 23 new species between 2017 and 2020 which were new to science, and Bhutan's biodiversity holds immense opportunities for researchers and environmental scientists as its biodiversity is in early stage of discovery.To date, Bhutan records 1 species as Extinct (EX), 1 species as Extinct in the Wild $(E W)$ and 134 species as Vulnerable (VU), Endangered (EN) and Critically Endangered (CR) under International Union of Conservation of Nature (IUCN) Red List of Threatened Species. This paper aims to report a checklist of globally threatened species listed in IUCN Red List of Threatened Species from Bhutan. The paper also lists down the new species that were discovered in Bhutan since 2017. More researchers are needed to discover new species from Bhutan's rich and lush forest.
\end{abstract}

Keywords: Threatened, Conservation, Biodiversity

\section{Introduction}

Bhutan, a landlocked kingdom between China and India, championed the conservation of environment before it joined any of the world bodies and conventions [22]. Bhutan lies in the Eastern Himalaya [3], with elevation ranging from 97 - 7570 meters above sea level (masl) [29]. The Eastern Himalaya range is one of the richest biodiversity hotspots covering 750,000 sq. km.[1] land area covering the Indian state of Sikkim, Arunachal Pradesh, Assam and West Bengal, Bhutan, Nepal, northern Myanmar and southeast Tibet (China)[26]. Bhutan is part of eight ecoregions, twenty-three important bird areas, important plant areas and wetlands with three Ramsar areas - Phobjikha, Khothokha and Bumdeling[17] [21].The constitution of the Royal Kingdom of Bhutan mandates to keep 60 percent of its land under forest cover for all time to come[28], the current land under forest cover is 71 percent[5]. More than half (51.44 percent) of the land is protected under National Parks (5), Wildlife Sanctuaries (4), Strict Nature Reserve (1), and biological corridors connecting different protected areas[6]. The country currently hosts 11,248 species within all taxa (figure 1) including the Black-necked Crane (Grusnigricollis), Great Hornbill (Bucerosbicornis), Rufousnecked Hornbill (Acerosnipalensis), White-bellied Heron (Ardeainsignis), Snow Leopard (Pantherauncia), Takin (Budorcastaxicolorwhitei), Chinese Pangolin (Manispentadactyla), Bhutan Swallowtail (Bhutanitisludlowi) and Blue Poppy (Meconopsisbhutanica) that are globally threatened[20] [21].

International Union for Conservation of Nature and Natural Resources (IUCN) was founded in 1948 to work in the field of natural resources and biodiversity conservation[25].The IUCN's Red List of Threatened Species was established in 1964and it is critical indicator of the health of biodiversity [31]. It is predicted that there are around 8.7 million species within all kingdom [19], where 14 percent species on land and 9 percent species in the ocean are described or documented[18]. 86 percent species on land and 91 percent species in the ocean await discovery and documentation[23] Currently, more than 120,000 species is documented by IUCN Red List of Threatened Species, with more than 32,000 species threatened with extinction including 14 percent of birds, 41 percent of amphibians, 33 percent of reef building corals, 34 percent of conifers and 26 percent mammals [4].

Bhutan's documentation of biological diversity is at early stage. Between 2009 and 2017, Bhutan recorded 16 plants [31], 4 snails [7], 1 dragonfly [15], 3 fishes [10], 2 beetles, 1 stonefly, 4 moths and 2 aphids that were new record for science [20]. Moreover Bhutan also recorded 566 new species including 5 birds, 35 snails and slugs, 59 dragonflies and damselflies, 65 bees and wasps, 1 trueflies, 44 amphibians and reptiles, 101 plants, 108 fishes, 4 beetles, 14 crabs, 4 butterflies, 119 moths, 5 cicadas, and 2 bryophytes in the same years [11]. The new species record for Bhutan has occurred at a rate of 62 species per year (62.88\%). Many of the species are not yet discovered and documented in Bhutan, there is a need for much research to document the undiscovered species (to science and Bhutan) and to understand species number and diversity [24] [21].

The study aims to study the threatened species of Bhutan listed in IUCN Red List from numerous published papers and books. There were many published paper on individual

Volume 10 Issue 2, February 2021

www.ijsr.net

Licensed Under Creative Commons Attribution CC BY 


\section{International Journal of Science and Research (IJSR) \\ ISSN: 2319-7064 \\ SJIF (2019): 7.583}

threatened species but a comprehensive full list of threatened species is not available. This paper also aims to list the new species discovered from Bhutan as we were not able to find any paper published after 2017 listing the new species to science.

\section{Methods and Materials}

The paper was prepared by going through the relevant published journal articles globally and nationally on checklist of IUCN Red List of Threatened Species available online. Google Scholar (www.scholar.google.com), Research Gate (www.researchgate.net), JSTOR (www.jstor.org), ProQuest (www.proquest.com), Nature (www.nature.com), Microsoft Academic (www.academic.microsoft.com), Directory of Open Access Journals (www.doaj.org), Science Direct (www.sciencedirect.com), South Asian Archive (www.southasiaarchive.com), Springer Link (www.springer.com), and Wiley Online Library (www.onlinelibrary.wiley.com) were used to search journal papers published since 2000. Distribution and occurrence data of species were extracted from iNaturalist (www.inaturalist.org), Bhutan Biodiversity Portal (www.biodiversity.bt), eBird (www.ebird.org) and IUCN Red List website (www.iucnredlist.org). The paper also lists those species that were discovered between 2017 and 2020 from Bhutan and were new to science in table 3. The data collected were interpreted using Microsoft Excel Spreadsheet and presented in a simple and informative way. The authors and organizations are cited well.

\section{Results and Discussions}

The IUCN Red List categorizes species under 9 categories based on specie's extinction risk[16]. The categories are Not Evaluated (NE), Data Deficient (DD), Least Concern (LC), Near Threatened (NT), Vulnerable (VU), Endangered (EN), Critically Endangered (CR), Extinct in the Wild (EW), and Extinct (EX)[16].

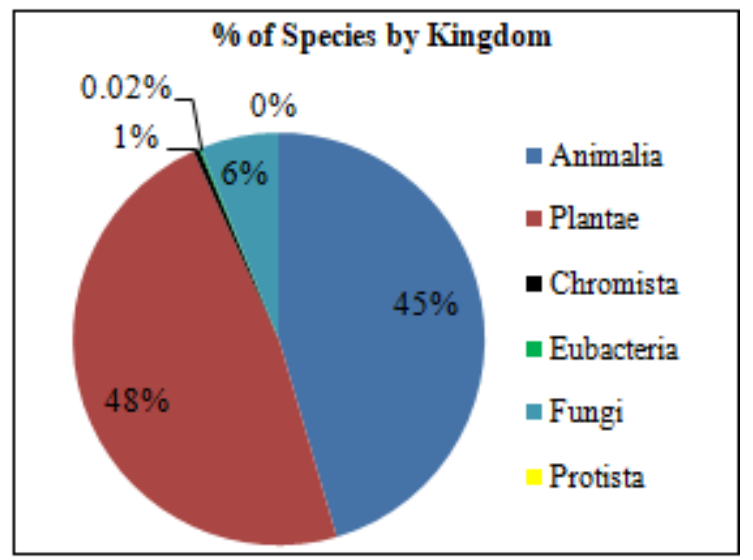

Figure 1: \% of Species by Kingdom in Bhutan

Out of $1,438,769$ [18] species in world, Bhutan is home to around 11,248 species (Table 1 \& Figure 1) [21]. 136 species are listed as globally threatened in the IUCN Red List of Threatened Species (Table 2 \&Figure 2)[30]. Out of 136 threatened species found in Bhutan, 1 is Extinct, 1 is
Extinct in the Wild and 134 of them are listed as Threatened, Critically Endangered and Vulnerable (Table 4). 1. 21 percent of Bhutan's biological diversity is threatened.

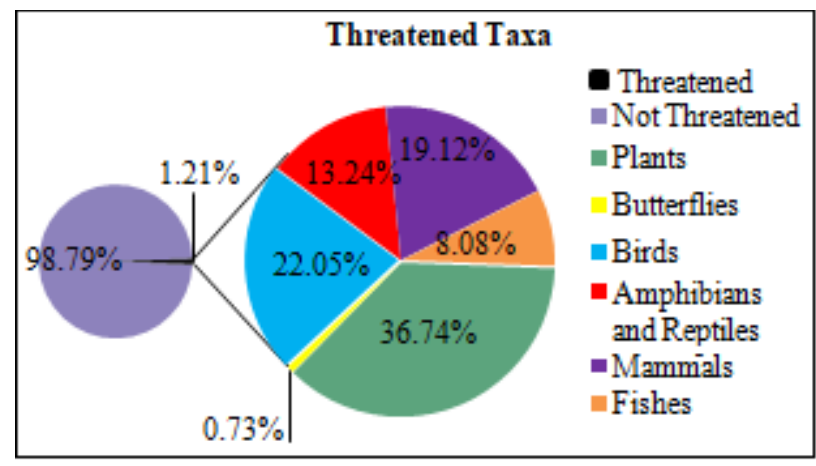

Figure 2: \% of Threatened taxa in Bhutan

Bhutan recorded 23 new species to science between 2017 and 2020. Bhutan's biodiversity is rich and not fully documented. If intense research is done in Bhutan's biodiversity, several new species to science would be discovered. There are ample of potential opportunities to future researchers. Spathogottisjetsuniae [13], orchid discovered in 2017, was named in honour of Her Majesty AzhiJetsun PemaWangchuck, Queen of Bhutan and Megalestesgyalsey [15], dragonfly discovered in 2017, was named in honour of His Highness Gyalsey Jigme Namgyel Wangchuck, Crown Prince of Bhutan.

\section{Conclusion}

While collecting and reviewing the scholarly works, we found out that there were not many papers published regarding checklist of IUCN Red List of Threatened Species and discovery of new species since 2017. The rate of consumption of natural resources, waste generation, economic development, illegal poaching and hunting possess threat to the survival of critically endangered species. Forest and Nature Conservation Act of Bhutan 1995 and Forest and Nature Conservation Rules and Regulations of Bhutan 2017 protect around 62 species, which are already listed as globally threatened under IUCN Red List of Threatened Species. Insufficient data poses major drawback to the management and conservation efforts. The paper also presents the list of new species that were discovered from Bhutan since 2017. More research need to be conducted to discover new species from Bhutan's rich and lush forest.

\section{Recommendation}

Bhutan is rich in biological diversity as news of new species discovered from Bhutan is shown every now and then. Many of the species are not yet discovered and documented in Bhutan, there is a need for much researches to be documented in the undiscovered species list (to science and Bhutan) and to understand species number and diversity. The younger generation interested in environment, biodiversity and research need to be taught the importance of species for our survival and encourage them to do more research basedin Bhutan. Our only hope is in younger minds and future generation. The incomplete data possess threats to species and hinders the conservation efforts.

\section{Volume 10 Issue 2, February 2021




\section{Competing Interests}

The authors declared that no conflict of interest exists in this work.

\section{References}

[1] Arunachalam, A., Sarmah, R., Adhikari, D., Majumder, M., \& Khan, M. L. (2004). Anthropogenic Threast and Biodiversity Conservation in Namdapha Nature Reserve in the Indian Eastern Himalaya. Current Science, 87(4), 447-454.

[2] Balkenohl, M. (2017, November). Trilophidius gemmatus sp. n., a New Species from Bhutan, with an Updated Identification Key to the Asian Species. Alpine Entomology, 1, 51-56.

[3] Banerjee, A., \& Bandopadhyay, R. (2016). Biodiversity Hotspot of Bhutan and its Sustainability. Current Science, 110(4), 521-527.

[4] Carbayo, F., \& Marques, A. C. (2011). The Costs of Describing the Entire Animal Kingdom. Trends in Ecology and Evolution, 26, 154-155.

[5] DoFPS. (2018). Forest Facts and Figures 2018. Thimphu, Bhutan: Department of Forest and Park Services, Ministry of Agriculture and Forest, Royal Government of Bhutan.

[6] Dorji, S., Rajaratnam, R., \& Vernes, K. (2012). THe Vulnerable Red Panda Ailurus fulgens in Bhutan: Distribution, Conservation Status and Management Recommendations. Oryx, 46(4), 536-543.

[7] Gittenberger, E., Leda, P., \& Sherub, S. (2017). Gastropods in Bhutan, the Genus Rahula (Pulmonata: Helicarionidae). Journal of Conchology, 42(6), 413418.

[8] Gittenberger, E., Leda, P., Sherub, S., \& Gergely, B. P. (2018, December 20). Endothyrella Zilch, 1960 in Bhutan (Gastropoda: Pulmonata: Plectopylidae), With a Description of Three New Species. Archiv fur Molluskenkunde, 147(2), 203-213.

[9] Gittenberger, E., Leda, P., Wangchuk, J., Gyeltshen, C., \& Stelbrink, B. (2020). The Genera Erhaia and Tricula (Gastropoda, Rissooidea, Amnicolidae and Pomatiopsidae) in Bhutan and Elsewhere in the Eastern Himalaya. ZooKeys, 929(12), 1-17.

[10] Gurung, D. B., \& Thoni, R. J. (2018). Morphological and Molecular Study of the Torrent Catfishes (Sisoridae: Glyptosterninae) of Bhutan Including the Description of Five New Species. Zootaxa, 4476(1), 040-068.

[11] Gyeltshen, C., Tobgay, K., Gyeltshen, N., Dorji, T., \& Dema, S. (2018). New Species Discoveries and Records in Bhutan Himalaya. (Hartmann, Barclay, \& Weipert, Eds.) Biodiversitat und Naturausstattung im Himalaya, VI.

[12] Gyeltshen, N., Gyeltshen, C., Tobgay, K., Dalstrom, S., Gurung, D. B., Gyeltshen, N., et al. (2020). Two New Spotted Chiloschista Species (Orchidaceae: Aeridinae) from Bhutan. Lankesteriana, 20(3), 281299.

[13] Gyeltshen, N., Tobgyel, K., \& Dalstrom, S. (2017). A New and Striking Spathoglottis (Orchidaceae: Collabiinae), Honouring Her Majesty the Queen of Bhutan. Lankesterian, 17(3), 395-401.
[14] Gyeltshen, P., Gurung, D. B., \& Kumar, P. (2020, March 16). Bulbophyllum trongsaense (Orchidaceae: Epidendroideae: Dendrobieae), a New Species From Bhutan. Phytotaxa, 436(1), 085-091.

[15] Gyeltshen, T., Kalkman, V. J., \& Orr, A. G. (2017). Honouring His Highness the Crown Prince of Bhutan: Megalestes gyalsey (Odonata: Synlestidae). Zootaxa, 4244(4), 588-594.

[16] IUCN. (2020). The IUCN Red List of Threatened Species. Retrieved October 12, 2020, from IUCN: https://www.iucnredlist.org

[17] Kubiszeski, I., Costanza, R., Dorji, L., Thoennes, P., \& Tshering, K. (2013). An Initial Estimate of the Value of Ecosystem Services in Bhutan. Ecoststem Services, 3, e11-e21.

[18] May, R. M. (1992). How Many Species Inhabit the Earth? Science Amer, 10, 18-24.

[19] Mora, C., Tittensor, D. P., Adl, S., Simpson, A. G., \& Worm, B. (2011). How Many Species Are There on Earth and in the Ocean? PLOS Biology, 9(8), e1001127.

[20] NBC. (2019). Biodiversity Statistics of Bhutan 2017. Thimphu, Bhutan: National Biodiversity of Bhutan, Minister of Agriculture and Forest, Serbithang.

[21] Nepal, T. K. (2020, November). Distribution and Threats of Rufous-necked Hornbill (Acerosnipalensis) in Bhutan. International Journal of Science and Research (IJSR), 9(11), 797-800.

[22] Pandit, M. K., Manish, K., \& Koh, L. P. (2014). Dancing on the Roof of the World: Ecological Transformation of the Himalaya Landscape. BioScience, 64(11), 980-992.

[23] Ricotta, C., Ferrari, M., \& Avena, G. (2002). Using the Scaling Behaviour of Higher Taxa for the Assessment of Species Richness. Biology Conservation, 107, 131133.

[24] Rinzin, C., Vermeulen, W. J., Wassen, M. J., \& Glasbergen, P. (2009, June). Nature Conservation and Human Well-Being in Bhutan. The Journal of Environment and Development, 18(2), 177-202.

[25] Rodrigues, A. S., Pilgrim, J. D., Lamoreux, J. F., Hoffmann, M., \& Brooks, T. M. (2006). The Value of the IUCN Red List for Conservation. TRENDS in Ecology and Evolution, 21(2), 71-76.

[26] Sano, M., Tshering, P., Komori, J., Fugita, K., Xu, C., \& Nakatsuka, T. (2013). May-September Precipitation in the Bhutan Himalay since 1743 as Reconstructed from Tree Ring Cellulose. Journal of Geophysical Research: Atmospheres, 118, 8399-8410.

[27] Smith, J., Zeegers, T., \& Dorji, P. (2020). A New Species of Eumerus (Diptera, Syrphidae) from the Kingdom of Bhutan, the Easternmost Representative of the Bacttrinus Subgroup. ZooKeys, 906, 141-151.

[28] Tobgay, S. (2015). The Constitution of Bhutan: Principles and Philosophies. Thimphu, Bhutan: Bhutan National Legal Studies.

[29] Tortajada, C., \& Saklani, U. (2018). Hydropowerbased Collaboration in South Asia: The Case of India and Bhutan. Energy Policy, 117, 316-325.

[30] UWICER. (2017). Hornbills: Connecting Environment, Economy and Culture in Bhutan. Lamai Goempa, Bumthang: Department of Forest and Park

\section{Volume 10 Issue 2, February 2021 www.ijsr.net}




\section{International Journal of Science and Research (IJSR) ISSN: 2319-7064 \\ SJIF (2019): 7.583}

Services, Ministry of Agriculture and Forests, Royal Government of Bhutan.

[31] Yoshida, T., Yangzom, R., \& Long, D. (2017). Dancing Butterflies of the East Himalayas - New Meconopsis Species From East Bhutan, Arunchal
Pardesh and South Tibet. Sibbaldia: The Journal of Botanic Garden Horticulture, 14, 69-96.

[32] Yoshida, T., Yangzom, R., \& Newman, M. F. (2017). Roscoea megalantha (Zingiberaceae). a New Species from Eastern Bhutan and India. Edinburgh Journal of Botany, 74(3), 1-9.

Table 1: Species Diversity of World and Bhutan

\begin{tabular}{|l|c|c|c|}
\hline Kingdom & World & Bhutan & Bhutan \% \\
\hline Plantae & 224,244 & 5,369 & 2.40 \\
\hline Animalia & $1,124.516$ & 5,114 & 0.46 \\
\hline Fungi & 44,368 & 690 & 1.56 \\
\hline Chromista & 17,892 & 55 & 0.31 \\
\hline Eubacteria & 11,010 & 18 & 0.16 \\
\hline Protista & 16,236 & 2 & 0.01 \\
\hline Archaebacteria & 503 & 0 & 0 \\
\hline \multicolumn{1}{|c|}{ Total } & $\mathbf{1 , 4 3 8 , 7 6 9}$ & $\mathbf{1 1 , 2 4 8}$ & $\mathbf{0 . 7 8} \%$ \\
\hline
\end{tabular}

Table 2: Threatened percentage of Biodiversity in Bhutan

\begin{tabular}{|c|c|c|c|}
\hline Order & Bhutan & Threatened & Threatened \% \\
\hline Plants & 5,369 & 50 & 0.93 \\
\hline Butterflies & 759 & 1 & 0.13 \\
\hline Birds & 752 & 30 & 4.98 \\
\hline Amphibians and Reptiles & 158 & 18 & 11.39 \\
\hline Mammals & 129 & 26 & 20.15 \\
\hline Fishes & 125 & 11 & 8.80 \\
\hline Total biodiversity & $\mathbf{1 1 , 2 4 8}$ & $\mathbf{1 3 6}$ & $\mathbf{1 . 2 0} \%$ \\
\hline
\end{tabular}

Table 3: New Species discovered in Bhutan (new to science) (2017-2020)

\begin{tabular}{|c|c|c|c|c|}
\hline Sl.No. & Groups & Species & Author (s) & Year \\
\hline 1 & \multirow{5}{*}{ Fishes } & Parachiloglanisdrukyulensis & D. B. Gurung \& R. J. Thoni [10] & 2018 \\
\hline 2 & & Parachiloglanisbenjii & D. B. Gurung \& R. J. Thoni [10] & 2018 \\
\hline 3 & & Parachiloglanisdangmechhuensis & D. B. Gurung \& R. J. Thoni [10] & 2018 \\
\hline 4 & & Exostomamangdechhuensis & D. B. Gurung \& R. J. Thoni [10] & 2018 \\
\hline 5 & & Creteuchiloglanisbumdelingensis & D. B. Gurung \& R. J. Thoni [10] & 2018 \\
\hline 6 & \multirow{8}{*}{ Plants } & Bulbophyllumtrongsaense & P. Gyeltshen, D. B. Gurung \& P. Kumar [14] & 2020 \\
\hline 7 & & Chiloschistahimalaica & $\begin{array}{l}\text { N. Gyeltshen, C. Gyeltshen, K. Tobgay, S. Dalstrom, D. B. Gurung, N. Gyeltshen } \\
\text { \& B. B. Ghalley [12] }\end{array}$ & 2020 \\
\hline 8 & & Chiloschistagelephuense & $\begin{array}{l}\text { N. Gyeltshen, C. Gyeltshen, K. Tobgay, S. Dalstrom, D. B. Gurung, N. Gyeltshen } \\
\text { \& B. B. Ghalley [12] }\end{array}$ & 2020 \\
\hline 9 & & Chiloschistadensiflora & $\begin{array}{l}\text { N. Gyeltshen, C. Gyeltshen, K. Tobgay, S. Dalstrom, D. B. Gurung, N. Gyeltshen } \\
\text { \& B. B. Ghalley [12] }\end{array}$ & 2020 \\
\hline 10 & & Roscoeamegalantha & T. Yoshida, R. Yangzom \& M. F. Newman [32] & 2017 \\
\hline 11 & & Meconopsisgakyidiana & T. Yoshida, R. Yangzom \& D. Long [31] & 2017 \\
\hline 12 & & Meconopsismerakensis & T. Yoshida, R. Yangzom \& D. Long [31] & 2017 \\
\hline 13 & & Spathogottisjetsuniae & N. Gyeltshen, K. Tobgyel \& T. Dalstrom [13] & 2017 \\
\hline 14 & \multirow{7}{*}{ Snails } & Erhaiapelkiae & E. Gittenberger, P. Leda, J. Wangchuk, C. Gyeltshen \& B. Stelbrink & 2020 \\
\hline 15 & & Erhaiajannei & E. Gittenberger, P. Leda, J. Wangchuk, C. Gyeltshen \& B. Stelbrink [9] & 2020 \\
\hline 16 & & Endothyrellabhutanensis & E. Gittenberger, P. Leda, S. Sherub \& B. P. Gergely [8] & 2018 \\
\hline 17 & & Endothyrellaspirostriata & E. Gittenberger, P. Leda, S. Sherub \& B. P. Gergely [8] & 2018 \\
\hline 18 & & Endothyrellapemagatshel & E. Gittenberger, P. Leda, S. Sherub \& B. P. Gergely [8] & 2018 \\
\hline 19 & & Rahulakleini & E. Gittenberger, P. Leda \& S. Sherub [7] & 2017 \\
\hline 20 & & Rahulatrongsaensis & E. Gittenberger, P. Leda \& S. Sherub [7] & 2017 \\
\hline 21 & Trueflies & Eumerusdruk & J. Smith, T. Zeegers\& P. Dorji [27] & 2020 \\
\hline 22 & Dragonflies & Megalestesgyalsey & T. Gyeltshen, V. J. Kalkman \& A. G. Orr [15] & 2017 \\
\hline 23 & Beetles & Trilophidiusgemmatus & M. Balkenohl [2] & 2017 \\
\hline
\end{tabular}

Table 4: List of IUCN Red List of Threatened Species in Bhutan

\begin{tabular}{|c|l|l|l|}
\hline S1. No. & \multicolumn{1}{|c|}{ Common Name } & \multicolumn{2}{c|}{ Mammals } \\
\hline \multicolumn{2}{|c|}{ Matogical Name } \\
\hline 1 & Chinese Pangolin & Manispentadactyla & Critically Endangered \\
\hline 2 & Pygmy Hog & Sussalvanius & Critically Endangered \\
\hline 3 & Dhole & Cuonalpinus & Endangered \\
\hline 4 & Bengal Tiger & Pantheratigristigris & Endangered \\
\hline 5 & Snow Leopard & Pantherauncia & Vulnerable \\
\hline 6 & Clouded Leopard & Neofelisnebulosa & Vulnerable \\
\hline
\end{tabular}

Volume 10 Issue 2, February 2021

www.ijsr.net

Licensed Under Creative Commons Attribution CC BY 
International Journal of Science and Research (IJSR)

ISSN: 2319-7064

SJIF (2019): 7.583

\begin{tabular}{|c|c|c|c|}
\hline 7 & Common Leopard & Pantherapardus & Vulnerable \\
\hline 8 & Golden Langur & Trachypithecusgeei & Endangered \\
\hline 9 & Capped Langur & Trachypithecuspileatus & Vulnerable \\
\hline 10 & Asian Small-clawed Otter & Anoxcinereus & Vulnerable \\
\hline 11 & Smooth-coated Otter & Lutrogaleperspicillata & Vulnerable \\
\hline 12 & Bearcat / Binturong & Arctictis binturong & Vulnerable \\
\hline 13 & Asiatic Black Bear & Ursusthibetanus & Vulnerable \\
\hline 14 & Indian Rhinoceros & Rhinoceros unicornis & Vulnerable \\
\hline 15 & Asian Elephant & Elephasmaximus & Endangered \\
\hline 16 & Himalayan Musk Deer & Moschusleucogaster & Endangered \\
\hline 17 & Alpine Musk Deer & Moschuschrysogaster & Endangered \\
\hline 18 & Bhutan Takin & Budorcastaxicolorwhitei & Vulnerable \\
\hline 19 & Sambar & Rusa unicolor & Vulnerable \\
\hline 20 & Gaur & Bosgaurus & Vulnerable \\
\hline 21 & Red Panda & Ailurusfulgens & Endangered \\
\hline 22 & Bengal Slow Loris & Nycticebusbengalensis & Vulnerable \\
\hline 23 & Hog Deer & Axis porcinus & Endangered \\
\hline 24 & Wild Water Buffalo & Bubalusarnee & Endangered \\
\hline 25 & Arunachal Macaque & Macacamunzala & Endangered \\
\hline 26 & Hispid Hare & Caprolagushispidus & Endangered \\
\hline \multicolumn{4}{|c|}{ Butterfly } \\
\hline 27 & Ludlow's Bhutan Swallowtail & Bhutanitisludlowi & Vulnerable \\
\hline \multicolumn{4}{|c|}{ Fishes } \\
\hline 28 & Walking Catfish & Clariasmagur & Endangered \\
\hline 29 & --- & Devarioassamensis & Vulnerable \\
\hline 30 & Loach & Aborichthysgaroensis & Vulnerable \\
\hline 31 & --- & Pterocryptisbarakensis & Endangered \\
\hline 32 & Golden Mahseer & Tor putitora & Endangered \\
\hline 33 & --- & Pseudecheneissirenica & Vulnerable \\
\hline 34 & Common Snow Trout & Schizothoraxrichardsonii & Vulnerable \\
\hline 35 & --- & Schisturainglisi & Vulnerable \\
\hline 36 & Assamese Kingfish & Cyprinuscarpio & Vulnerable \\
\hline 37 & Mrigal Carp & Cirrhinuscirrhosus & Vulnerable \\
\hline 38 & European Carp & Cyprinuscarpio & Vulnerable \\
\hline \multicolumn{4}{|c|}{ Amphibians and Reptiles } \\
\hline 39 & Indian Peacock Softshell Turtle & Nilssoniahurum & Vulnerable \\
\hline 40 & Nankiang Horned Toad & Xenophrysnankiangensis & Vulnerable \\
\hline 41 & Gharial & Gavialisgangeticus & Critically Endangered \\
\hline 42 & Three-striped Roofed Turtle & Kachungadhongoko & Endangered \\
\hline 43 & Indian Roofed Turtle & Kachugakachuga & Critically Endangered \\
\hline 44 & Southeast Asian Box Turtle & Cuoraamboinensis & Vulnerable \\
\hline 45 & Elongata Tortoise & Indotestudoelongata & Endangered \\
\hline 46 & Crowned River Turtle & Hardellathurjii & Vulnerable \\
\hline 47 & Keeled Box Turtle & Cuoramouhotii & Endangered \\
\hline 48 & Spotted Pond Turtle & Geoclemyshamiltonii & Vulnerable \\
\hline 49 & Assam Roofed Turtle & Pangshurasylhetensis & Endangered \\
\hline 50 & Burmese Python & Python bivittatus & Vulnerable \\
\hline 51 & Narrow-headed Softshell Turtle & Chitraindica & Endangered \\
\hline 52 & King Cobra & Ophiophagushannah & Vulnerable \\
\hline 53 & Asian Rock Python & Python molurus & Vulnerable \\
\hline 54 & Indian Eyed Turtle & Moreniapetersi & Vulnerable \\
\hline 55 & Walnut Kukri Snake & Oligodonjuglandifer & Vulnerable \\
\hline 56 & Tricarinate Hill Turtle & Melanochelystricarinata & Vulenerable \\
\hline \multicolumn{4}{|c|}{ Birds } \\
\hline 57 & Kashmir Flycatcher & Ficedulasubrubra & Vulnerable \\
\hline 58 & Black-necked Crane & Grusnigricolis & Vulnerable \\
\hline 59 & Blyth's Tragopan & Tragopanblythii & Vulnerable \\
\hline 60 & Red-headed Vulture & Sarcogypscalvus & Critically Endangered \\
\hline 61 & Steppe Eagle & Aquila nipalensis & Endangered \\
\hline 62 & Rustic Bunting & Emberizarustica & Vulnerable \\
\hline 63 & White-rumped Vulture & Gyps bengalensis & Critically Endangered \\
\hline 64 & Pallas's Fish Eagle & Haliaeetusleucoryphus & Endangered \\
\hline 65 & White-bellied Heron & Ardeainsignis & Critically Endangered \\
\hline 66 & White-winged Duck & Asarcornisscutulata & Endangered \\
\hline 67 & Baer's Pochard & Aythyabaeri & Critically Endangered \\
\hline 68 & Egyptian Vulture & Neophronpercnopterus & Endangered \\
\hline 69 & Common Pochard & Aythyaferina & Vulnerable \\
\hline
\end{tabular}

Volume 10 Issue 2, February 2021

www.ijsr.net

Licensed Under Creative Commons Attribution CC BY 
International Journal of Science and Research (IJSR)

ISSN: 2319-7064

SJIF (2019): 7.583

\begin{tabular}{|c|c|c|c|}
\hline 70 & Beautiful Nuthatch & Sittaformosa & Vulnerable \\
\hline 71 & Wood Snipe & Gallinagonemoricola & Vulnerable \\
\hline 72 & Indian Spotted Eagle & Clangahastata & Vulnerable \\
\hline 73 & Hodgson's Bushchat & Saxicolainsignis & Vulnerable \\
\hline 74 & Lesser Adjutant & Leptoptilosjavanicus & Vulnerable \\
\hline 75 & Great Hornbill & Bucerosbicornis & Vulnerable \\
\hline 76 & Rufous-necked Hornbill & Acerosnipalensis & Vulnerable \\
\hline 77 & Long-tailed Duck & Clangulahyemalis & Vulnerable \\
\hline 78 & Wreathed Hornbill & Rhyticerosundulatus & Vulnerable \\
\hline 79 & Woolly-necked Stork & Ciconiaepiscopus & Vulnerable \\
\hline 80 & Grey-sided Thrush & Turdusfeae & Vulnerable \\
\hline 81 & Greater Spotted Eagle & Clangaclanga & Vulnerable \\
\hline 82 & Chestnut-breasted Partridge & Arborophilamandellii & Vulnerable \\
\hline 83 & Dark-rumped Swift & Apusacuticauda & Vulnerable \\
\hline 84 & Eastern Imperial Eagle & Aquila heliaca & Vulnerable \\
\hline 85 & Grey-crowned Prinia & Priniacinereocapilla & Vulnerable \\
\hline 86 & Great Slaty Woodpecker & Mulleripicuspulverulentus & Vulnerable \\
\hline \multicolumn{4}{|c|}{ Plants } \\
\hline 87 & Bhutanese Blue Poppy & Meconopsisbhutanica & Critically Endangered \\
\hline 88 & --- & Sorbuslingshiensis & Critically Endangered \\
\hline 89 & The Striped Petal & Eulophiastenopetala & Extinct \\
\hline 90 & --- & Bulleyiayunnanensis & Endangered \\
\hline 91 & Sargent Spruce & Piceabrachytyla & Vulnerable \\
\hline 92 & --- & Ilex venulosa & Endangered \\
\hline 93 & --- & Meconopsissuperba & Endangered \\
\hline 94 & --- & Carexnigradrukyulensis & Endangered \\
\hline 95 & Mangalore Aglaia & Aglaiaperviridis & Vulnerable \\
\hline 96 & Heart-shaped Slipper Orchid & Cypripedium cordigerum & Vulnerable \\
\hline 97 & White Angel Trumpet & Brugmansiasuaveolens & Extinct in the Wild \\
\hline 98 & --- & Ophiorrhizalongii & Critically Endangered \\
\hline 99 & --- & Bistortagriersonii & Endangered \\
\hline 100 & Jatamansi & Nardostachysjatamansi & Critically Endangered \\
\hline 101 & $\begin{array}{ll}-- \\
--\end{array}$ & Androsacehemisphaerica & Endangered \\
\hline 102 & Agarwood, Aloeswood, Eaglewood & Aquilariamalaccensis & Critically Endangered \\
\hline 103 & --- & Onosmagriersonii & Critically Endangered \\
\hline 104 & --- & Astragalusparoensis & Critically Endangered \\
\hline 105 & Crown Wand Orchid & Paphiopedilumfairrieanum & Critically Endangered \\
\hline 106 & --- & Bambusaclavata & Vulnerable \\
\hline 107 & --- & Saxifragavacillans & Vulnerable \\
\hline 108 & Himalayan Slipper Orchid & Cypripedium himalaicum & Endangered \\
\hline 109 & --- & Pedicularissanguilimbata & Endangered \\
\hline 110 & Montrey Cypress & Cupressusmacrocarpa & Vulnerable \\
\hline 111 & --- & Strobilanthesaccrescensaccrescens & Endangered \\
\hline 112 & --- & Hypericumsherriffii & Endangered \\
\hline 113 & --- & Cymbopogonbhutanicus & Vulnerable \\
\hline 114 & Fern Tree, Blue Jacaranda, Black Poui & Jacaranda mimosifolia & Vulnerable \\
\hline 115 & Spicer's Slipper Orchid & Paphiopedilumspicerianum & Endangered \\
\hline 116 & Himalayan Yew & Taxuswallichiana & Endangered \\
\hline 117 & --- & Rhododendron dalhousiae var. rhabdotum & Vulnerable \\
\hline 118 & --- & Illiciumgriffithii & Endangered \\
\hline 119 & --- & Ceropegiabhutanica & Endangered \\
\hline 120 & --- & Buddlejabhutanica & Vulnerable \\
\hline 121 & --- & Pedicularisgriniformis & Vulnerable \\
\hline 122 & --- & Sorbusrinzenii & Endangered \\
\hline 123 & --- & Corallodiscuscooperi & Vulnerable \\
\hline 124 & Leopard Spotted Bulbophyllum & Bulbophyllumleopardinum var. tuberculatum & Critically Endangered \\
\hline 125 & Adder's Mouth & Malaxismuscifera & Vulnerable \\
\hline 126 & --- & Cheirostylissherriffii & Critically Endangered \\
\hline 127 & --- & Neopicrorhiza minima & Endangered \\
\hline 128 & PanduaGogan & Saurauiapunduana & Critically Endangered \\
\hline 129 & Assam Cycas & Cycaspectinata & Vulnerable \\
\hline 130 & --- & Ceropegiadorjei & Critically Endangered \\
\hline 131 & Wax Plant & Hoya bhutanica & Endangered \\
\hline 132 & --- & Oreorchissanguinea & Critically Endangered \\
\hline 133 & --- & Isodonatroruber & Endangered \\
\hline 134 & --- & Drepanostachyumannulatum & Vulnerable \\
\hline 135 & --- & Cypripedium elegans & Endangered \\
\hline
\end{tabular}

Volume 10 Issue 2, February 2021

www.ijsr.net

Licensed Under Creative Commons Attribution CC BY 
Volume 10 Issue 2, February 2021

www.ijsr.net

Licensed Under Creative Commons Attribution CC BY 